\title{
Here Today, Gone Tomorrow - Political Ambition, Coalitions, and Accountability as Determinants of Ministerial Turnover in the Brazilian Multiparty Presidential System
}

\author{
Pedro Lucas de Moura Pallotti
}

https://orcid.org/0000-0002-9071-9726

Instituto de Pesquisa Econômica Aplicada, Brasília, Distrito Federal, Brazil

Pedro Luiz Costa Cavalcante

https://orcid.org/0000-0001-7635-695X

Instituto de Pesquisa Econômica Aplicada, Brasília, Distrito Federal, Brazil

\author{
Juliana Betini Fachini Gomes \\ https://orcid.org/0000-0002-6677-4768
}

Universidade de Brasília, Brasília, DF, Brazil

The article aims at understanding the determinants of ministerial turnover in presidential systems. There are essentially three key factors that govern the propensity for ministerial turnover in a presidential system: 01 . political ambition - reflected in the individual or collective strategies and tactics employed by the party-affiliated actors represented in the cabinet; 02 . the presence or absence of a governing coalition - which has bearing on the degree of ideological distance between the president and such political parties as form part of any governing coalition, with consequences for ministerial scrutiny; and 03. accountability - a determinant in responding to such external pressures as may be brought to bear by public opinion. In order to investigate the impacts of these factors, this inquiry seeks to analyze the new and dynamic democracy of Brazil. Brazil's presidential system presents interesting features that make it an excellent laboratory in which to test hypotheses concerning every aspect of ministerial turnover. To this end, this paper employs a multivariate methodology, as well as descriptive and survival analyses, based on a comprehensive and original database of cabinet ministers that draws on three presidencies over five democratically elected governments from 1995 to 2014 . Among other results, our most original finding was that there is an inverse correlation between the degree of ministerial politicization (political ambition) and ideological distance from the president during political scandals (interaction between the governing coalition and accountability) on the one hand, and the length of ministerial tenure on the other.

Keywords: Cabinet appointments; presidential system; ministerial turnover; Brazil.

http://dx.doi.org/10.1590/1981-3821201900020009

For data replication, see: https://doi.org/10.7910/DVN/V3LLLE

This publication is registered under a CC-BY Licence. 
$\mathrm{T}$ his article aims at understanding the determinants of ministerial turnover in multiparty presidential systems. Such elements as the structure of the party to which the president belongs, the institutional features of the electoral and party system, the existence of political and social support groups, in addition to regional, ethnic and religious issues, as well as variables related to the individual capacities and interests of ministers, together contribute to the multivariate nature, dynamism and elevated complexity of ministerial appointments and resignations.

In theory, there are essentially three key factors that govern the propensity for ministerial turnover in a presidential system: 01. political ambition - reflected in the individual or collective strategies and tactics employed by the party-affiliated actors represented in the cabinet; 02. the presence or absence of a governing coalition - which has bearing on the degree of ideological distance between the president and such political parties as form part of any governing coalition, with consequences for ministerial scrutiny; and 03. accountability - a determinant in responding to such external pressures as may be brought to bear by public opinion in response to unsatisfactory performance or media reporting of a corruption scandal. The first two of these three factors relate to principal-agent theory and the third to external shock adaptation; together they can explain key assumptions in regard to ministerial turnover in multiparty governments.

In order to investigate the impacts of these factors, this inquiry seeks to analyze the new and dynamic democracy of Brazil. Brazil's presidential system presents interesting features that make it an excellent laboratory in which to test hypotheses concerning every aspect of ministerial turnover.

First, there are the institutional arrangements of the Brazilian federative republic, with its three spheres of government, fragmented party system and biannual elections for the Executive and Legislative branches. These foster favorable conditions for any minister who may be inclined to resign and run for another office in a highly competitive political system. This being the case, political ambition may explain individuals or groups of ministers leaving office before a given presidential term has ended. 
The framework of Brazil's political system, so-called 'coalition presidentialism', exerts a powerful influence on the selection and potential dismissal of cabinet members, given that it involves deliberated calculations in a multifaceted environment. The literature on the matter makes it clear that the Chief of the Executive (i.e., the president) must take into consideration the proportionality of party representation in Congress, as well as the representation of social groups and regions (ABRANCHES, 1988; AMORIM NETO, 2006; CODATO and FRANZ, 2018; D'ARAUJO and RIBEIRO, 2018; FIGUEIREDO and LIMONGI, 1999; PALOTTI and CAVALCANTE, 2018). The scenario becomes even more complex and challenging in a multiparty system where there are some thirty parties represented in the Legislative branch and the proportion of seats held by the president's party seldom reaches 20\%. The structure of Brazilian 'coalition presidentialism' is in effect supported by a range of parties with different ideological positions. This enables us to analyze whether the degree of ideological distance between the president and the parties forming the governing coalition entails consequences in terms of the scrutiny to which individual ministers are subjected.

The third factor, accountability, provides a particularly rich seam in the case of Brazil, with its compendious history of recurring political scandals, mostly related to corruption. The assumption underlying the presumed motive of accountability is that presidential decisions to fire ministers occur due to external pressures coming from public opinion or within the political system in response to unsatisfactory performance or media reporting of corruption scandals. As demonstrated by Araújo, Costa and Fittipaldi (2016), the greater a party's ideological divergence vis-à-vis the president, the likelier it was to be affected by dismissals in response to media reporting of corruption during the first Rousseff administration. Without question, coalition management in a government with a single-party cabinet would present an entirely different scenario. For one thing, the president's ability to exercise scrutiny over ministers would be less constrained, and this would have consequences for ministerial turnover.

In the more than two decades since the reestablishment of democracy in Brazil, political science has made significant progress in investigating ExecutiveLegislative relations. Nevertheless, little progress has been made on the influence of multiparty coalitions on the modus operandi of the Executive branch. 
Recent advances have been made in understanding the public profiles of cabinet ministers and the role they play in presidential decisions on appointments. The combination of perceived political experience and administrative competence can have a mollifying effect on hostile public opinion (CODATO and FRANZ, 2018; D'ARAUJO and RIBEIRO, 2018; PALOTTI and CAVALCANTE, 2018). Relatively speaking, however, the reasons for ministerial resignations and dismissals remain under-investigated.

Ministerial churn may be interpreted as a sign that the administrative capacity of the government is undergoing renewal or that government leaders are sensitive to public opinion, particularly in cases where a minister is removed from office due to involvement in a corruption scandal. It may, however, have negative implications for policy implementation by reducing the time available to the administration. This can lead to projects being interrupted and institutional know-how being lost. In the long term, aspiring public servants may feel dissuaded from pursuing a career in the public service. These undesirable consequences are frequently identified in specialized literature, particularly in the Latin American context where turnover is historically high.

So, under what conditions and for what reasons do presidents replace cabinet members? This paper discusses the extent to which ministerial tenure is subject to the fortunes of coalitions, influenced by the dilemmas a president faces when appointing and monitoring the performance of ministers, and liable to external pressures imposed by public opinion. Furthermore, this study seeks to explain why the top non-elected official in a presidential system might leave government before the end of a term; in other words, it seeks to explain the determinants of ministerial turnover.

It therefore makes important contributions to the literature on minister survival in a democratic context. The main findings of this study are: firstly, the importance of political connections in explaining cabinet tenure. The key factor here is the political ambition of political actors, itself explained by the divergent preferences between actors and the principal. Secondly, although presidents care about the accountability of institutions, they respond differently to external shocks like political scandals. This is due to the constraints inherent in coalition 
governments. When confronted with sandals exposed by the media, presidents tend to fire ministers from parties whose ideologies diverge most from their own. This finding represents an original explanation for minister turnover in coalition governments faced with external shocks. Ministerial turnover is in the main explicable by reference to the political ambitions of ministers plus the president's decision to substitute a cabinet member, based on the factors outlined above. Thirdly, this study provides a more extensive and multi-causal overview of Brazilian ministerial turnover than previous works in the field of political science.

In addition to this introduction, this paper is organized in four sections. The first discusses the literature on government formation in presidential systems. The second presents the authors' hypotheses. The third provides some descriptive statistics regarding ministerial turnover in Brazil. The fourth section describes the regression models and their results. In the final remarks, the hypotheses are discussed and some conclusions are proposed.

\section{The literature on cabinet formation in presidential systems}

Ministers are key actors in the functioning of governments. They are political agents empowered to influence the legislative and executive agendas, and occupy positions of leadership in their organizations and policy areas. Therefore, when a president appoints or substitutes a minister, he or she sends an important message to a large number of actors. This has policy, political and symbolic implications, with consequences for public policy and governability.

Research on government formation in presidential systems focuses on three areas: coalitional presidentialism, minister recruitment and minister turnover (CAMERLO and MARTÍNEZ-GALLARDO, 2018). Coalitional presidentialism relates to the politics of forming a legislative coalition in order for the executive to be able to govern, and relies primarily on party linkages and institutional arrangements as sources of political support(AMORIM NETO, 2006; DRUCKMAN and WARWICK, 2005). Minister recruitment relates to ministers' profiles, and seeks to investigate recruitment strategies with reference to professional backgrounds and political or social linkages in executive formation. Non-party-affiliated ministers are the subject of considerable discussion in the literature, given the variety of 
interpretations of their roles as ministers (ESCOBAR-LEMMON and TAYLORROBINSON, 2010; GROSSMAN and FRANÇOIS, 2013).

The third area of presidential government formation research is ministerial turnover, which is the object of two distinct analytical approaches: principal-agent theory and external shock adaptation (CAMERLO and MARTÍNEZGALLARDO, 2018). Initially, ministerial turnover was regarded as a political tool for leveraging alliances among the parties in a coalition government. The resignation of a minister may result from a policy difference with the president on the part of the minister's party or the minister him/herself; alternatively, resignation may be necessitated by the exigencies of the electoral calendar. A president may also realize his or her own error in making a specific ministerial appointment, especially in a complex political context, such as a multiparty presidential government or parliamentary system (DIERMEIER and MERLO, 2000; FISCHER and KAISER, 2008; HUBER and MARTÍNEZ-GALLARDO, 2008).

In parliamentary systems, the tenure of individual ministers (cabinet turnover) presents a different dynamic to that of coalition government (length of cabinet). Since ministers frequently survive government breakdowns, their tenure is weakly associated with cabinet succession (HUBER and MARTINEZ-GALLARDO, 2008). In Icelandic parliamentarism, the average number of ministers replaced every year is half that of the United Kingdom. Possible explanations for this discrepancy include a closer alignment of opinion between the prime minister and his/her cabinet members in Iceland than in the UK, differences between the modus operandi of the Icelandic media and that of their British counterparts, and that fact that the Icelandic government model operates with fewer ministries than does its Westminster equivalent (KRISTINSSON, 2009). Furthermore, Iceland has a small number of ministerial positions available. The presence of dismissed - and resentful - ministers in its small parliament could be detrimental to the workings of government (DOWDING and DUMONT, 2009).

Another common feature of parliamentary systems is the principle of collective responsibility, which limits the prime minister's freedom to replace individual ministers. Decisions on appointments tend to be made collectively, involving negotiations with any coalition members and internal party factions (DOWDING and 
DUMONT, 2009; STRØM, 2000). In Italy, the principle of collective responsibility played a decisive role in the workings of the First Republic. The prime minister's limited autonomy hindered the holding of individual ministers to account. The Second Italian Republic saw a strengthening of the office of the prime minister. This occurred due a number of popular personalities occupying the post and using their prestige to dismiss or replace ministers without approval from the entire cabinet although the influence of coalition partners tended to limit this discretion (VERZICHELLI, 2009).

In presidential systems, ministerial turnover can reflect conflicts taking place in the political arena. Escobar-Lemmon and Taylor-Robinson (2010) have looked at the cases of the United States, Costa Rica, Colombia, Chile and Argentina. They found that ministers consistently survived in cabinets where they were connected to ministry 'clients'. They also demonstrate that finance ministers are at greater risk of leaving their cabinets than other ministers, while 'insider' politicians have a lower risk of switching posts than surviving in the cabinet. The president's loyal friends are less likely to be dismissed than remain in office, even though they face greater risk of being fired. Members of political families are more likely to be dismissed.

Finally, some scholars argue that State organization at multiple levels of government as well as in international arrangements present intervening variables vis-à-vis ministerial turnover. In some situations, ministers leave cabinets to occupy prestigious positions in international organizations, such as the United Nations or the European Union. In other cases, they may leave office to take up posts in lower levels of government. Spain and Belgium are examples of countries where mid-level ministers may aspire to attractive positions at the local government level, which ultimately impacts "the chief of the Executive's ability to keep even his most talented ministers" (DOWDING and DUMONT, 2009, p. 12).

Those explanations for minister turnover are theoretically related to principal-agent theory. An individual minister's tenure is a consequence of poor selection or moral hazard problems. Poor selection here refers to the selection of a minister by his or her president without thoroughgoing scrutiny. This allows the minister to hide his or her true qualifications or policy preferences; this being especially pertinent when the minister comes from a party whose ideology diverges from the president's. Moral hazard presents the second difficulty. 
Divergences between principals and agents are derived from their divergent preferences. Monitoring therefore becomes difficult, as agents use their asymmetric access to information and knowledge to gain benefits in the form of political advantages or to ignore the president's or party goals to pursue their own. This challenge becomes greater when ministers have multiple principals, such as the president and their political party (DIXIT, 1997; GAILMARD, 2009).

In this paper, principal-agent theory is employed to explain how political ambition and government coalitions contribute to ministerial turnover. Since 1988, multiparty coalition has been a strategy used by Brazilian presidents to form governments. They typically abide by an informal rule, according to which cabinet positions are allocated among different political parties. The ability to hire and fire ministers is one of the president's main levers of power (PEREIRA, BERTHOLINI and RAILE, 2016; RAILE, PEREIRA and POWER, 2011). Principal-agent theory therefore provides a suitable mechanism for explaining the Brazilian political system.

Another possible explanation for minister turnover lies in how the chief of the executive responds to external shocks. Replacing a minister may be perceived as addressing demands from interest groups or protesters (responsiveness), or as an attempt to purge the government of malefactors suspected of corruption and/or abuse of power (accountability). However, cabinet reshuffles can lead to conflicts within government coalitions; they may also signal high levels of political volatility (CAMERLO and MARTÍNEZ-GALLARDO, 2018; CAMERLO and PÉREZLIÑÁN, 2015a; GROSSMAN, 2009; HUBER, 1998; STEIN et al., 2006).

Reshuffles can also hamper policy implementation by promoting 'shorttermism' (HUBER, 1998; HUBER and MARTÍNEZ-GALLARDO, 2008; MARTÍNEZGALLARDO, 2010). They can act as a source of perverse incentives and impede the achievement of policy goals:

In general, when there is uncertainty as to whether a politician will be in office in the next term, politicians do not fully internalize the costs associated with their choices for public policies [...] and become unable to credibly commit themselves to inter-temporal arrangements. In terms of cabinet policy, a certain degree of stability is also needed to promote long-term policies and to support the implementation of programs and policies in their completeness [...]. In the literature, cabinet instability has also been associated with the breakdown of relations of accountability between politicians and bureaucrats, with weak 
accumulation of experience and instability and inconsistent public policies (MARTÍNEZ-GALLARDO, 2010, pp. 137-138).

In Germany, individual substitutions tend to be more associated to personal enrichment or traffic of influence than to managerial motivations, such as poor performance or misconduct (FISCHER and KAISER, 2009). In Portugal, during more than thirty years (from 1976 to 2005), less than 10\% of replaced ministers had had no prior political careers. It can be assumed that the autonomy of prime ministers was not constrained by pressures from political parties to replace ministers. Thus 'independents' became so important to the 'quality' of cabinets that the prime minister had to think twice before dismissing them (PINTO and ALMEIDA, 2009, p. 157).

Camerlo and Pérez-Liñán (2015a) used a database covering 12 Latin American countries over the period 1979 to 2007 to investigate the effects of critical events and election calendars on ministerial turnover ${ }^{1}$. Their findings indicated that political clashes - such as protests against ministers and involvement in corruption scandals - had an effect on cabinet turnover, but that such effects were tempered by electoral projections and the desire to avoid the lame duck effect ${ }^{2}$. In the Argentinean case, Camerlo and Pérez-Liñán (2013b) developed an analysis based on three ministerial profiles: politicians, technocrats, and loyal friends (cronies). Ministerial stability was linked with the popularity of the president and the existence or absence of economic recession. In scenarios of declining presidential

\footnotetext{
${ }^{1}$ The case of Latin America highlights key reasons for ministerial turnover. Focusing on Latin America from 1990 to 2003, Martínez-Gallardo (2010) argues that ministerial stability is lower than in other regions. Despite some differences between these systems, she demonstrates that in most of the region's countries, ministers retain their posts, on average, for approximately one third of a presidential term; the exceptions are Chile, Mexico, Costa Rica, and Uruguay, where ministers stay in their posts for over half a presidential term. Another relevant aspect is the average number of appointments per ministry. The countries with the lowest average number of ministers were Chile, Mexico and Uruguay, with approximately 04 to 06 ministers per ministry. In Ecuador, Peru, Colombia and Bolivia there were more than 10 ministers, on average, per portfolio, during the period analyzed. Ministerial instability and high turnover rates impede the effective implementation of public policies in the region.

${ }^{2}$ Presidents are characterized in the literature as lame ducks when they are likely to be out of office within a short timeframe, either because they were not re-elected, chose not to run again or were limited by some institutional constraint, such as ineligibility to run in new elections. In these situations, presidents are expected to have less political influence over other politicians, such as those making up a legislative coalition, and devote themselves to unilateral and sometimes controversial or unpopular acts with a view to their long-term legacy (CAMERLO and PÉREZLIÑÁN, 2015a).
} 
popularity, a minister's ideological alignment with his or her president had no bearing on tenure. Conversely, in cases of rising presidential popularity, more aligned ministers are dismissed more frequently than less aligned ones. These results show that a cabinet reshuffle can be a proactive tool and is not only used as a reactive strategy when faced with external difficulties.

In this paper, the theory of external shock adaptation corresponds to the accountability factor. Brazil has 30 years of interrupted democracy with a free press, as well as independent auditing and control agencies and a vigilant public (MELO and PEREIRA, 2013). This creates a propitious environment for ministerial turnover, especially when ministers are accused by media of unsatisfactory performance or involvement in corruption. Figure 01 synthesizes our theoretical approach to minister turnover.

Figure 01. The theoretical framework for ministerial turnover

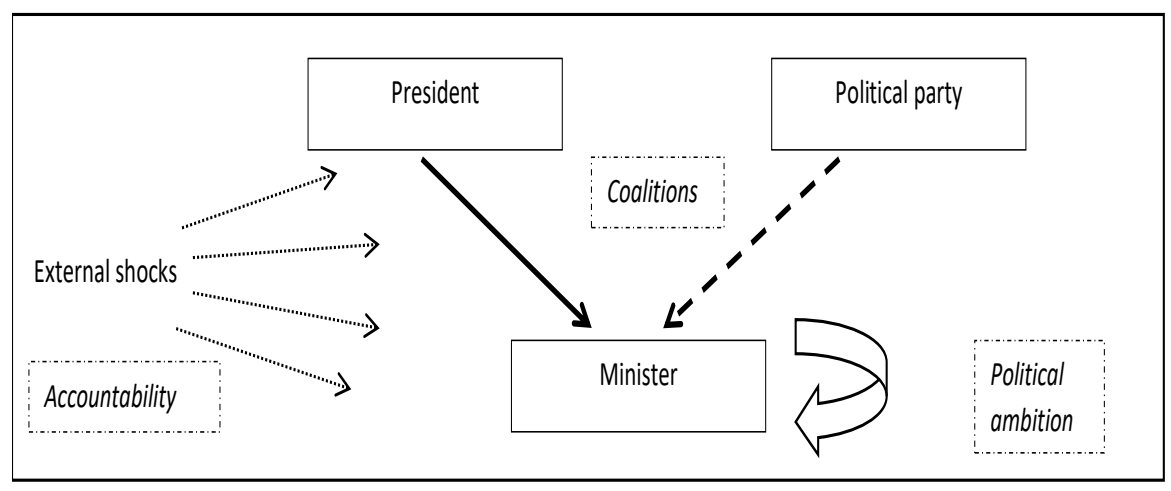

Source: Elaborated by the authors.

While coalition formation and its consequences for the relationship between executive and legislative powers has been extensively investigated, few studies have been devoted to understanding the durability of ministers that test for both principal-agent theory (here characterized as both political ambition and government coalition) and external shock adaptation (here as accountability). Over the following paragraphs, our research hypotheses, grounded in these three main explanatory assumptions mentioned above, are presented and discussed. 


\section{Political ambition}

The literature on ministerial turnover emphasizes the importance of attributes related to the career and political trajectory of politicians in the top governmental positions as explanatory factors for shorter tenure. (CAMERLO and PÉREZ-LIÑÁN, 2013a, 2013b; ESCOBAR-LEMMON and TAYLOR-ROBINSON, 2010). Other factors, together, can lead to shorter ministerial tenure, such as the need to represent their parties in elections, decisions made by party leaders to break with the coalition-forming party, or a lack of connections with experts in the field, which can hamper their performance in their portfolios.

Furthermore, ministers who are members of political parties are subject to scrutiny by the chief of the Executive and their own political party's leaders. The existence of more than one 'principal' in a delegation relationship, as well as institutional and political incentives for greater monitoring of delegated powers are relevant factors to explain the pattern of ministerial turnover (HUBER and MARTÍNEZ-GALLARDO, 2004; MARTÍNEZ-GALLARDO and SCHLEITER, 2014; STRØM, 2000 ). Thus, the increased politicization of ministerial appointments may correlate to a lower probability of survival over a presidential term. In the Brazilian case, Cavalcante and Palotti (2018) find evidence of this.

H1: The higher the minister's degree of politicization, the shorter his or her tenure in the ministry.

To measure ministers' levels of politicization, we used the Index of Ministerial Politicization (IMP) ${ }^{3}$, an indicator initially developed by Borges and Coelho (2015), with some adjustments (PALOTTI and CAVALCANTE, 2018). The index includes variables regarding political performance - linkages with political parties (affiliation and administrative positions within parties) and experience as an elected official - and technical background - level of education, careers in the public sector, and managerial experience. These variables were organized using

\footnotetext{
${ }^{3}$ The database was mainly based on biographies gathered by the Center for Research and Documentation of the Contemporary History of Brazil (CPDOC) at the Getúlio Vargas Foundation, with complementary data gathered by searching the Internet and referring to the historical collections of two Brazilian newspapers: Folha de São Paulo and Estadão. The reference was always the minister's profile at the time of appointment.
} 
publicly available information about each minister. The IMP uses a seven-point scale (ranging from 0 to 06 ), as follows:

The IPM scale has seven points, from 0 to 06 , which add up to the sum of six binary variables.

a. Party affiliation: being affiliated to a political party when appointed Minister; (Yes - 01 point);

b. Elected position: having been elected to any office (in the executive or legislative branches, at any level of government) prior to appointment to the position of minister; (Yes - 01 point);

c. Position in party administration: having held a position in the administrative structure of the political party (national presidency, state or municipal presidency, general secretary, treasury etc., including in its foundation); (Yes - 01 point);

d. Academic training: holding an academic degree at a master's or doctoral level; (No - 01 point);

e) Public or military servants: have previously pursued a career in the military or as a public servant; (No - 01 point);

f) Management experience in the area: having held managerial positions directly related to the post subsequently occupied as minister, at the national or subnational level; (No - 01 point).

The Cronbach's Alpha of the IMP is 0.74. It is therefore above the parameter of 0.70 , considered the minimum threshold to indicate the existence of unidimensionality in the observed factor (HAIR JR. et al., 2014). The lower end (values 0 and 01 ) represents ministers with a predominantly technical profile who specialize in policy, while the upper end includes politicians, with strong party ties and political backgrounds (values 05 and 06).

\section{Government coalitions}

The existence of broad governmental coalitions directly influences agency relations between the president and party leaders and the chief of the Executive and ministers (agents), mainly in their selection and the monitoring of their performance. Therefore, as in multiparty parliamentarism, in presidential systems, 
the president negotiates posts and scrutinizes the profiles under consideration for appointment.

The rationale underlying this process is that presidents will attempt to examine the profiles so to avoid subsequent problems derived from poor selection. However, in a game that involves leaders of political parties who are more ideologically distant from the president, there is always the possibility of moral hazard associated with ministerial performance. In the expression used by Huber and Martínez-Gallardo (2008, p. 172), more distant ministers can cause "public policy damage" by their performance, which causes them to be more carefully monitored by the chief of the Executive vis-à-vis those ideologically closer to the president.

Considering the features of Brazilian coalition presidentialism, the following research hypothesis is tested:

H2: The greater the ideological distance between the president's party and the party of the minister, the shorter their tenure in the ministry.

\section{Accountability}

Public opinion can directly affect the length of time ministers are in their positions. Camerlo and Pérez-Liñán (2015a) explain that critical events - such as protests against ministers and corruption scandals - along with the elections calendar, especially if there is the possibility of reelection, affect the likelihood of ministers leaving the cabinet prematurely.

In presidential systems with broad multiparty coalitions, like Brazil's, it is assumed that presidents will be more likely to dismiss ministers appointed by their government partners when they are involved in media-reported scandals. Because they face fewer constraints on the formation of their cabinet than chiefs of the Executive in parliamentary systems, presidents can more openly punish deviant behavior by representatives of allied parties (DOWDING and DUMONT, 2009). They choose to tolerate or find other ways out (ministerial substitutions or other possible appointments) for ministers from their own party and those without party affiliation, who are in general ideologically closer to the president.

From the beginning of the first Rousseff administration, Araújo, Costa and Fittipaldi (2016) identified the president's responsiveness to corruption scandals. However, she kept ministers from her own party in cabinet and dismissed those 
from allied parties. The greater the ideological distance of these parties from the president's party, the greater the likelihood of dismissal. Thus, it is assumed that Brazilian presidents are sensitive to corruption scandals. Nevertheless, they tend to spare their closest allies and punish more ideologically distant partners more severely, that is, the presence of government coalitions influences the pattern of presidential responsiveness.

H3: The involvement of a minister in media-reported scandals reduces his/her tenure.

There are, however, ministers who are closer and others who are more distant from the president and their party. This leads to differential treatment in their appointment and, where necessary, their substitution. The hypothesis below traces an interactive effect between coalitions and the occurrence of scandals.

H3.1: In cases of involvement in media-reported scandals, more ideologically distant ministers tend to stay for less time in their positions than ministers who are ideologically closer to the president;

Before testing these hypotheses, the next section will describe the Brazilian case, based on the main descriptive numbers concerning ministerial turnover and its causes.

\section{Here today, gone tomorrow: ministerial turnover in Brazil}

This section addresses the following questions: do ministers in Brazil remain in office across successive governments? Is there variability that needs to be better understood? If turnover rates are high, are they symptomatic of conditions within a specific administration or do they reflect a broader phenomenon?

Based on data on all Brazilian presidential appointments, the findings discussed by Martínez-Gallardo (2010) were confirmed: there is a significant variance in the turnover of ministers both over and between presidential terms. The variable used is the length (in days) of the presidential terms of office between 1995 and 2014. This descriptive estimate was carried out with the use of survival analysis to model determinants of the end of a ministerial appointment prior to the end of a presidential term. This is the event to be modeled. 
It is not advisable to extract central tendency measures normally analyzed in descriptive statistics, as these include censored data that create biases in the estimates $^{4}$. An alternative is to obtain the median survival time, with the expectation that approximately $50 \%$ of ministers leave their positions. We used the KaplanMeier estimator to estimate the maximum likelihood of survival. For the period studied, the median time was 932 days, which represents approximately $65 \%$ of a presidential term.

Figure 02 shows the probability of ministers surviving the event of interest, and can be used to estimate the median survival time in a presidential term. There are significant variations between terms. Fernando Henrique Cardoso's two presidential terms were extreme cases. His first term had a median survival time for ministers of 1215 days, indicating that they stayed in office longer than ministers under other presidents. His second term, however, had the shortest median time, a mere 686 days.

Figure 02. Probability of ministerial survival by presidential term (1995 - 2014)

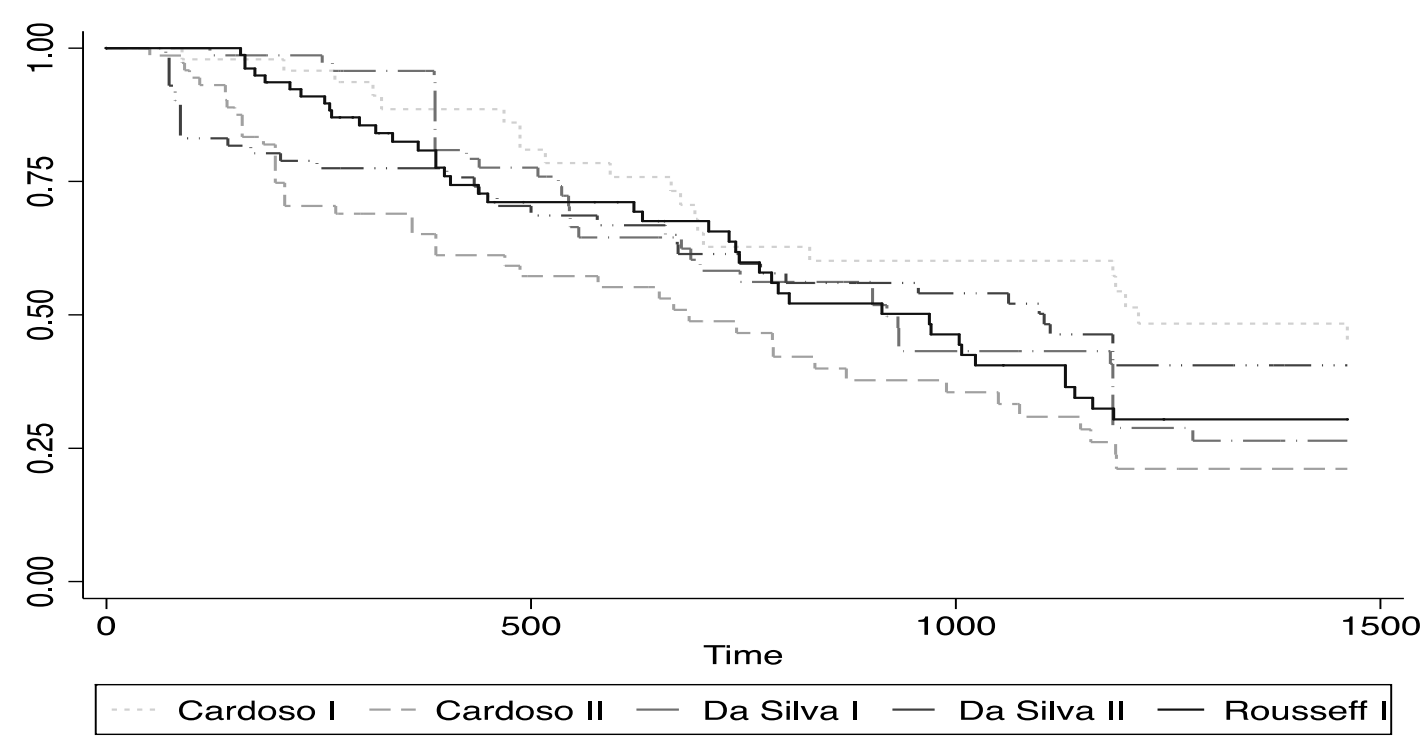

Source: Authors' own elaboration from data collected for Brazil.

${ }^{4}$ Censors occur when the event of interest (in this case, leaving the cabinet or changing ministries before the end of the presidential term) did not occur during the observation time. This measure is an improvement on the figures presented by Martínez-Gallardo (2010). 
During the PT (Partido dos Trabalhadores - Workers' Party) governments, the second da Silva's administration exhibited low ministerial rotation, with 1104 days' median survival. In that and the first Rousseff administration, the tenures were broadly similar, with ministers remaining in cabinet for a median 919 and 969 days respectively. This behavior provides evidence of significant differences in presidential style in contexts of varied adversity, given the noticeable differences between administrations under the same president ${ }^{5}$.

Reasons for leaving cabinet can be grouped into four main possibilities, according to the division presented by Escobar-Lemmon and Taylor-Robinson (2010). Based on their taxonomy, in the period from 1995 to 2014, as shown in Figure 03, the number of ministers who remained in office until the end of their presidential terms amounted to $47 \%$ of all appointments. This group is denominated the 'Survivors'. Figure 03 shows the ministers that were dismissed by their presidents, mainly due conflicts or disasters involving public policies, personal scandals or corruption allegations. These accounted for $10 \%$ of the total number and are known as the 'Tragic Ending' cohort. 11\% of total appointments corresponded to ministers who were moved from one ministry to another, the socalled 'Migrators'. Lastly, a more heterogeneous set of reasons, ranging from the abolition of certain ministries, substantive changes and/or disruptions to coalition arrangements, resignation and/or departure from office to run in an election accounted for the remaining 30\% of cases ('Exit by choice or convenience'). Approximately one third of such exits occurred because of election or re-election to a public position. Less than $1 \%$ were either not identified, or due to death or health reasons ('other reasons/unidentified').

One advantage of adopting the classification proposed by Escobar-Lemmon and Taylor-Robinson (2010) is the possibility of using the aggregated data, collected by the authors for other presidential systems, for comparison with the Brazilian case. Table 01 shows that Brazil's rate of ministerial survival throughout a presidential term is close to the mean for the countries investigated. Only Costa Rica and - to an even greater extent - the United States had lower turnovers than

\footnotetext{
${ }^{5}$ When applied to each of the five presidential terms, The Wilcoxon test confirms this statement. The hypothesis of similarity between the curves is rejected, as chi2 $(4)=15.89$, the $p=0.003$.
} 
Brazil. The figure for Migrators is also close to the average for the other countries, although Argentina, Chile and the USA represented extreme counter-examples. The Brazilian scenario for the Tragic Ending cohort is similar to those of Chile and the United States, but below the average for the other countries.

Figure 03. Reasons for leaving appointed office (1995 -2014)

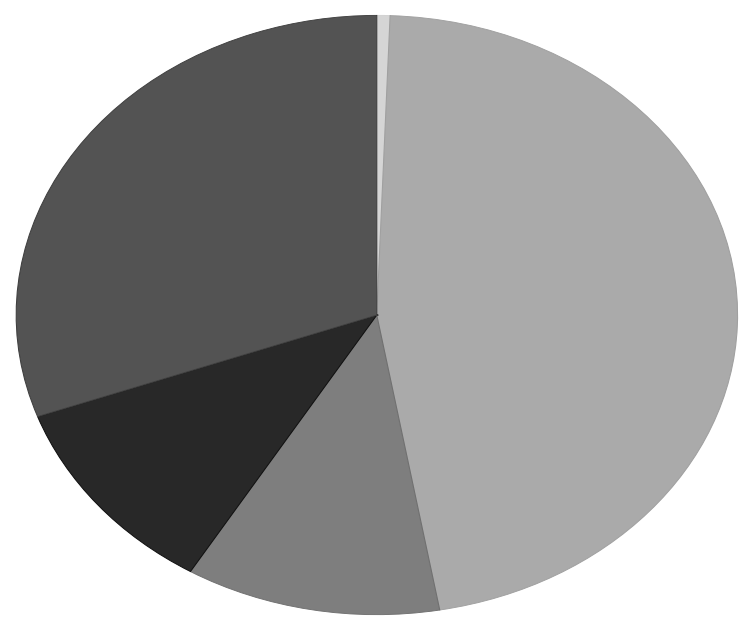

Other reasons / unidentified Migrators

Survivors

Exit by choice or convenience

Source: Authors' own elaboration from data collected for Brazil.

Table 01. Reasons for ministers leaving office - country comparison

\begin{tabular}{lccccccc} 
& Brazil & Argentina & Chile & Colombia & Costa Rica & USA & Total \\
\cline { 2 - 7 } Survivors & $47 \%$ & $41 \%$ & $44 \%$ & $45 \%$ & $50 \%$ & $74 \%$ & $50 \%$ \\
Migrators & $11 \%$ & $19 \%$ & $18 \%$ & $14 \%$ & $10 \%$ & $3 \%$ & $13 \%$ \\
$\begin{array}{l}\text { Tragic Ending } \\
\text { Exit by choice or }\end{array}$ & $11 \%$ & $28 \%$ & $12 \%$ & $21 \%$ & $21 \%$ & $8 \%$ & $17 \%$ \\
convenience & $31 \%$ & $12 \%$ & $26 \%$ & $20 \%$ & $19 \%$ & $15 \%$ & $20 \%$ \\
Total & $100 \%$ & $100 \%$ & $100 \%$ & $100 \%$ & $100 \%$ & $100 \%$ & $100 \%$
\end{tabular}

Source: Authors' own elaboration from data collected for Brazil, and from data collected by Escobar-Lemmon and Taylor-Robinson (2010) for the other countries reviewed.

Obs.: For Brazil, ministers who left cabinet for unidentified or other reasons were added to the category 'Out of choice or convenience', following the convention made by EscobarLemmon and Taylor-Robinson (2010). The periods of government analyzed for each of the countries are: Brazil (1995-2014); Argentina (1999-2010); Chile (2000-2010); Colombia (1998-2010); Costa Rica (1998-2010); and the USA (1993-2009). 
Other reasons for exit from office accounted for more than $30 \%$ of cases in Brazil, which is above the average of the other countries and close to that of Chile. Our analysis found that one third of exits were associated with resignation to run in an election, and another third due to changes in cabinet relating to intra-coalition politics. These findings are similar to those for Chile. Thus, from a comparative perspective, Brazil's ministerial turnover trends do not constitute especially disruptive characteristics. Brazilian ministerial turnover is high in comparison to parliamentary systems ${ }^{6}$, but similar to those found in other presidential governments in Latin America.

These data on ministerial turnover must, however, be carefully interpreted. Pinto and Almeida (2009, p. 155) warn about the limitations of mapping the reasons for ministerial tenure ending. According to them, "the real motives are often hidden from the public". For instance, unsatisfactory performance may be presented as a difference of opinion. In the Brazilian case, it is reasonable to assume that the low rate of tragic endings may be the result of agreements between ministers and presidents to treat them as resignations so as to avoid further damage to the reputation of the erstwhile minister and/or his party or the government in the court of public opinion.

This paper's statistical analyses therefore address the set of motivations that led ministers to leave office before the end of their presidential term. In this sense we hope to avoid subjective or inferred classifications based on limited publicly-available information.

\section{The determinants of ministerial turnover}

\section{Data and methods}

To address these hypotheses, this paper uses a comprehensive and original database of cabinet appointments that covers three recent presidencies over five different democratically-elected administrations from 1995 to 20147 .

\footnotetext{
${ }^{6}$ Huber and Martínez-Gallardo (2008) have analyzed individual minister rotation determinants in parliamentary systems. Of the 19 countries surveyed, only in Ireland does the cabinet end date coincide with the date most ministers leave office. For all others, the governments ended before their ministers' terms in office, i.e., ministers tended to remain in office from one government to the next.

${ }^{7}$ The main sources for the database were the biographies held in the Center for Research and Documentation of the Contemporary History of Brazil (CPDOC) at the Getúlio Vargas Foundation. Complementary sources were the Internet and the historical collections of two Brazilian newspapers: Folha de São Paulo and Estadão.
} 
Considering the dependent variable description, survival analysis will be used as a statistical tool, with minister tenure expressed in days. As Huber and Martínez-Gallardo (2008, p. 174) have pointed out, these models "are very useful precisely when the dependent variable of interest is the time for the occurrence of a terminal event (or a fault) - in this case the exit of a cabinet minister".

The terminal event (or fault) is therefore a ministerial departure from office before the relevant presidential term expires. Migration of a minister from one ministry to another will also be considered a terminal event (or fault). The objective is to arrive at an understanding of all of the possible reasons for ministerial turnover. We have not differentiated between dismissals and resignations, since the officially released documents concerning such cases are unreliable as sources. It is commonplace, after having been pressured into resignation by president or party, for a minister to announce publicly that his or her exit was made for personal reasons. Further study of this area, requiring a qualitative approach, presents enticing prospects for future research.

The longest a minister can stay in office is 1461 days, being the full four years of a presidential term. Observations on terms without failures have been censored. The same individual can be appointed to more than one role. This allows the survival model to be applied without needing to consider the effects of covariates on tenure. A similar strategy was applied by González-Bustamante and Olivares (2016).

Unlike in other studies in this area, we did not find any justification for the application of fragility ${ }^{8}$. Our model does not compare countries with each other, as did those of Huber and Martínez-Gallardo (2008) and Escobar-Lemmon and TaylorRobinson (2010), therefore we needed to adjust estimates coming from a cluster, in this case from the same country. None of the variables identified in the literature as having an impact on ministerial turnover, such as the locus of an appointment, media-reported scandals, protests, presidential popularity, or macroeconomic

\footnotetext{
${ }^{8}$ Fragility was applied to survival analysis models when important variables were not included, either due to the data being incomplete or not collectable, or when the survival time could have a much greater variability than explained by the model, with super-dispersion. In such cases, fragility acts to introduce random effects.
} 
variables, were omitted, as González-Bustamante and Olivares (2016) deliberately did not consider them ${ }^{9}$.

Since minister turnover is, obviously, a multivariate subject, some control variables were also included in the statistical model. Among them are sociodemographics - race, sex, age, and region of the country (in this case, being from São Paulo or not) - and party linkage. A binary variable was introduced for ministerial appointments to the initial cabinet. Although not central to the research, some findings in the literature helped infer the expected behavior for these control variables. Escobar-Lemmon and Taylor-Robinson (2010) point out that women are not replaced more quickly than men. They also find that ministers appointed during the initial cabinet tend to spend less time in their positions than others, due to problems deriving from poor selection. Berlinski et al. (2009) note that younger ministers are more likely than older ministers to exit cabinet positions of their own volition, since, for the latter, such a move may coincide with the end of their careers. The relevance of the regional dimension is emphasized in the literature (D'ARAUJO and RIBEIRO, 2018; DOWDING and DUMONT, 2009). More especially, the distinct effect of a minister coming from São Paulo seems interesting, not only because it is the country's richest state, but also due to the fact that the parties whose candidates occupied the presidency during the period under analysis (the PT and the PSDB (Partido da Social Democracia Brasileira - Brazilian Social Democracy Party)) were formed in São Paulo state, and the majority of their leaders were of São Paulo provenance. The model also includes the area of government, a variable that separates ministries according to their policy field: core ministries; public policy implementation; political articulation and state functions; and the presidency and minor ministers (PALOTTI and CAVALCANTE, 2018). Two other variables are added to the model to determine their effect on tenure: being a minister from a traditional political family (with relatives in politics); and having a personal relationship with the president. The sources of these variables are the authors' database, as explained above.

\footnotetext{
${ }^{9}$ To confirm this assumption, the likelihood ratio test after the application of fragility does not reject the null hypothesis that the variance of the fragilities is zero (chibar2 (01) $=0.00$; Prob $>=$ chibar2 $=$ 1.000).
} 
Finally, variables that measure the president's popularity, unemployment and inflation were also employed. As the president is expected to react to these indicators, the values for the three months leading up to the dismissal of a minister were taken into consideration. Popular presidents tend to have more alternatives to exhaust before reshuffling their cabinets, and therefore use this strategy less than their unpopular counterparts (MARTINEZ-GALLARDO, 2011) ${ }^{10}$. However, when faced with media-reported scandals, dismissals may be necessary to improve the popularity of the chief of the Executive (DOWDING and DUMONT, 2009). It is assumed that increased unemployment and inflation rates, both provided by the Brazilian Institute of Geography and Statistics (IBGE), will correlate to greater ministerial turnover. Internal and external shocks that cause economic crises tend to be countered by cabinet reshuffles, and can indicate a change in policy direction ${ }^{11}$. Table 02 presents a synthesis of the relationship between variables in the model, and the expected effect on ministerial stability.

Table 02. Relationship between variables in the model and the expected effect on ministerial stability

\begin{tabular}{lc}
\multicolumn{1}{c}{ Variables } & $\begin{array}{c}\text { Expected effect on ministerial } \\
\text { stability }\end{array}$ \\
\hline Index of Ministerial Politicization (IMP) & $(-)$ \\
Party affiliation & $(+)$ \\
Same party as president & $(-)$ \\
Allied base & $(-)$ \\
Ideological difference & $(-)$ \\
Scandal & $(-)$ \\
Protest & \\
Areas of government & $(-)$ \\
Core ministries & $(+)$ \\
Public Policy Implementation & $(-)$ \\
Area of political articulation and State functions & $(-)$ \\
Presidency and minor ministers & $(+)$ \\
Family members of politicians & $(+)$ \\
Friends of the president &
\end{tabular}

${ }^{10}$ The data correspond to the percentage of respondents who evaluated the government's performance as 'great' and/or 'good'. The data were obtained though research carried out by CNIIBOPE and Datafolha, with the use of simple interpolation, measured for the three months preceding a ministerial dismissal. Available at http://datafolha.folha.uol.com.br/opiniaopublica/index.shtml\# and http://www.portaldaindustria.com.br/estatisticas/pesquisa-cnil-ibope-avaliacao-do-governo/.

${ }^{11} \mathrm{As}$ the data do not obey the risk proportionality assumption, it is not possible to use the Cox model. Statistical tests were performed to estimate data distribution, thus the Weibull parametric model was adopted. 


\begin{tabular}{lc}
\multicolumn{1}{c}{ bpsr } & $\begin{array}{l}\text { Here Today, Gone Tomorrow - Political Ambition, } \\
\text { Coalitions, and Accountability as Determinants of } \\
\text { Ministerial Turnover in the Brazilian Multiparty } \\
\text { Presidential System }\end{array}$ \\
\hline Ministerial clients & $(+)$ \\
Women & $(+)$ \\
Afro-Brazilians & $(-)$ \\
Age & $(+)$ \\
São Paulo & $(+)$ \\
Initial Cabinet & $(-)$ \\
Popularity & $(+)$ \\
Unemployment & $(-)$ \\
Inflation & $(-)$ \\
\hline
\end{tabular}

Source: Authors' own elaboration from data collected for Brazil.

\section{Descriptive analysis}

Initially some exploratory analyses were performed in order to map the effects of independent variables on survival time. From the analyses developed, and taking into account survival analysis, we gave due consideration to the IMP, different areas of government and involvement in media-reported scandals. Because they are categorical, these variables can be graphically visualized in survival curves using the Kaplan-Meier estimator. In Figure 04, seven distinct curves relating to the IMP are depicted, one for each level, from zero to six. To facilitate visualization, the greater the politicization of a ministerial appointment, the darker the line.

It is observed that the dark lines, representing greater politicization, begin their terms presenting similar behavior. Over time (specifically, just before the 500-day mark), the dark lines reach their nadir - indicating minimum probability of survival. This preliminary result shows that the higher the degree of politicization, the greater the likelihood of leaving cabinet, especially after a certain time in office. The Wilcoxon test points out the existence of (chi2 (6) $=13.83 ; p=0.0315)$.

Figure 05 shows the survival curves when dividing government by clusters of political attractiveness ${ }^{12}$. In these cases, it is observed that the core and implementation area lines are always below the other lines, indicating lower probability of survival for the ministers in these areas. The area that includes

\footnotetext{
${ }^{12}$ The division of ministries into four areas of political attractiveness was proposed by Palotti (2017), from five variables selected by Mauerberg Jr. (2016): a) total budget; b) discretionary transfers; c) networking; d) total of civil servants; and e) patronage. The variables correspond to factors that point to a greater or lesser existence of political assets in respect of said ministries.
} 
presidential secretaries and minors ministries tends to resemble the political articulation and state areas. Over time, however, the latter isolates itself as the area with the greatest probability of prolonged ministerial tenure. The Wilcoxon test confirms the assumption of statistically significant differences between the curves $(\operatorname{chi} 2(3)=8.51 ; p=0.0366)$.

Figure 04. Survival curves for the index of ministerial politicization (KaplanMeier)

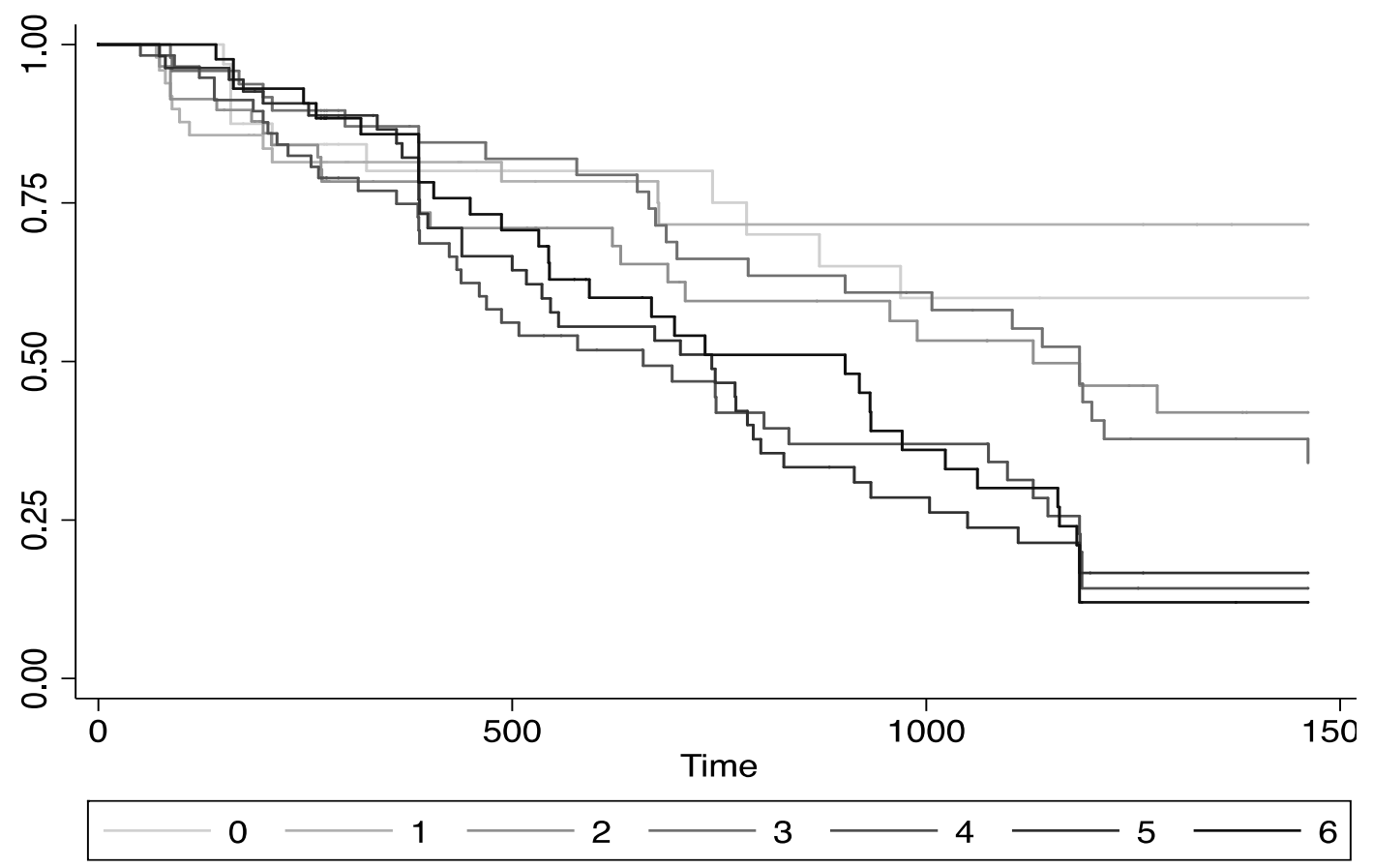

Source: Authors' own elaboration from data collected for Brazil.

Next, we can observe the behavior of the survival function when mediareported scandals occur during a minister's time in office. As can be seen from Figure 06, early in the presidential term, ministers with or without involvement in scandals tend to remain in cabinet for equal amounts of time, and in the short term those involved in scandals tend to survive more than those who are not. Thereafter, the curves tend to separate gradually. Ministers not involved in media-reported scandals tend to survive longer in cabinet. 
Figure 05. Survival curves for areas of government (Kaplan-Meier)

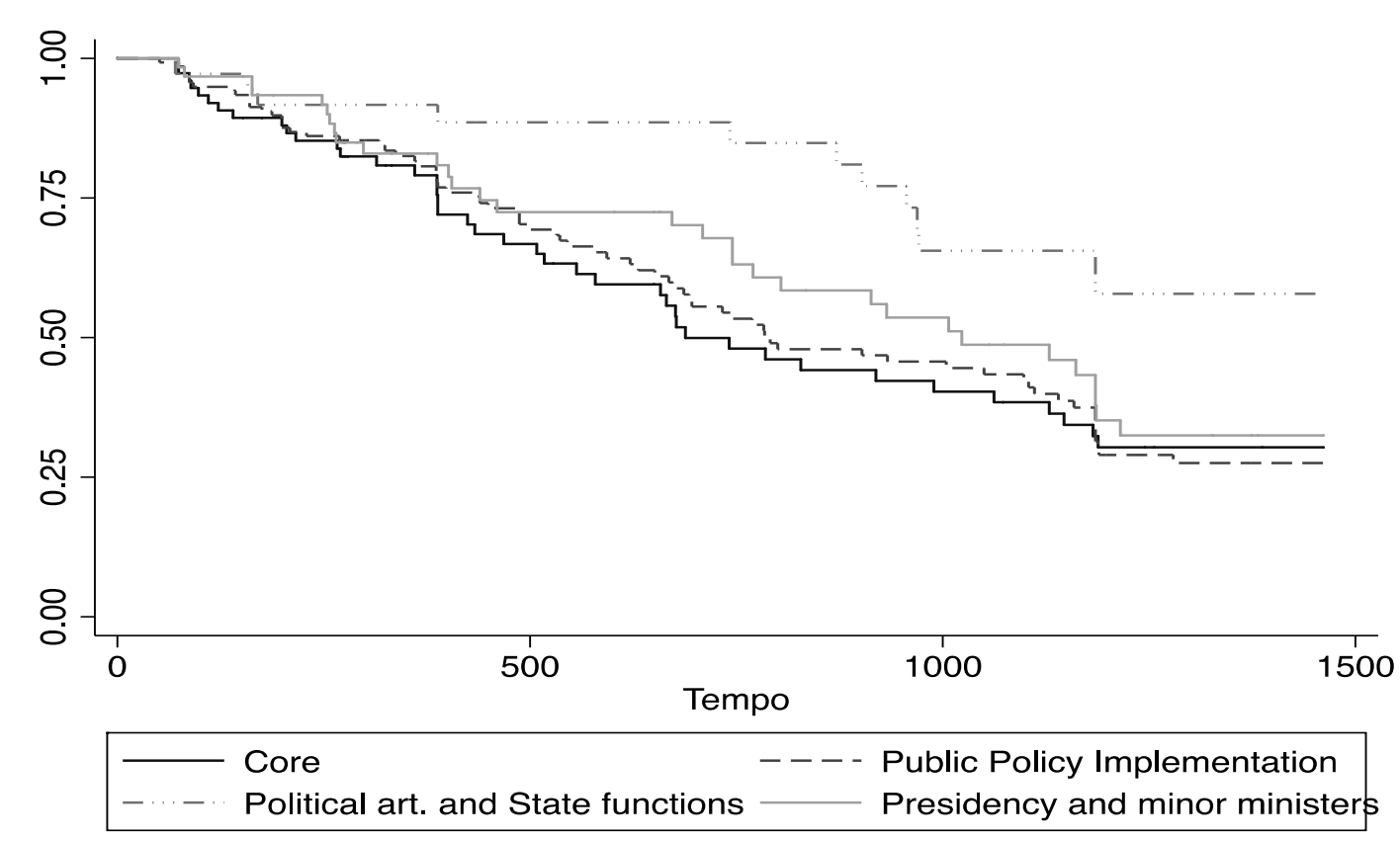

Source: Authors' own elaboration from data collected for Brazil.

Figure 06. Survival curves for media-reported scandals (Kaplan-Meier)

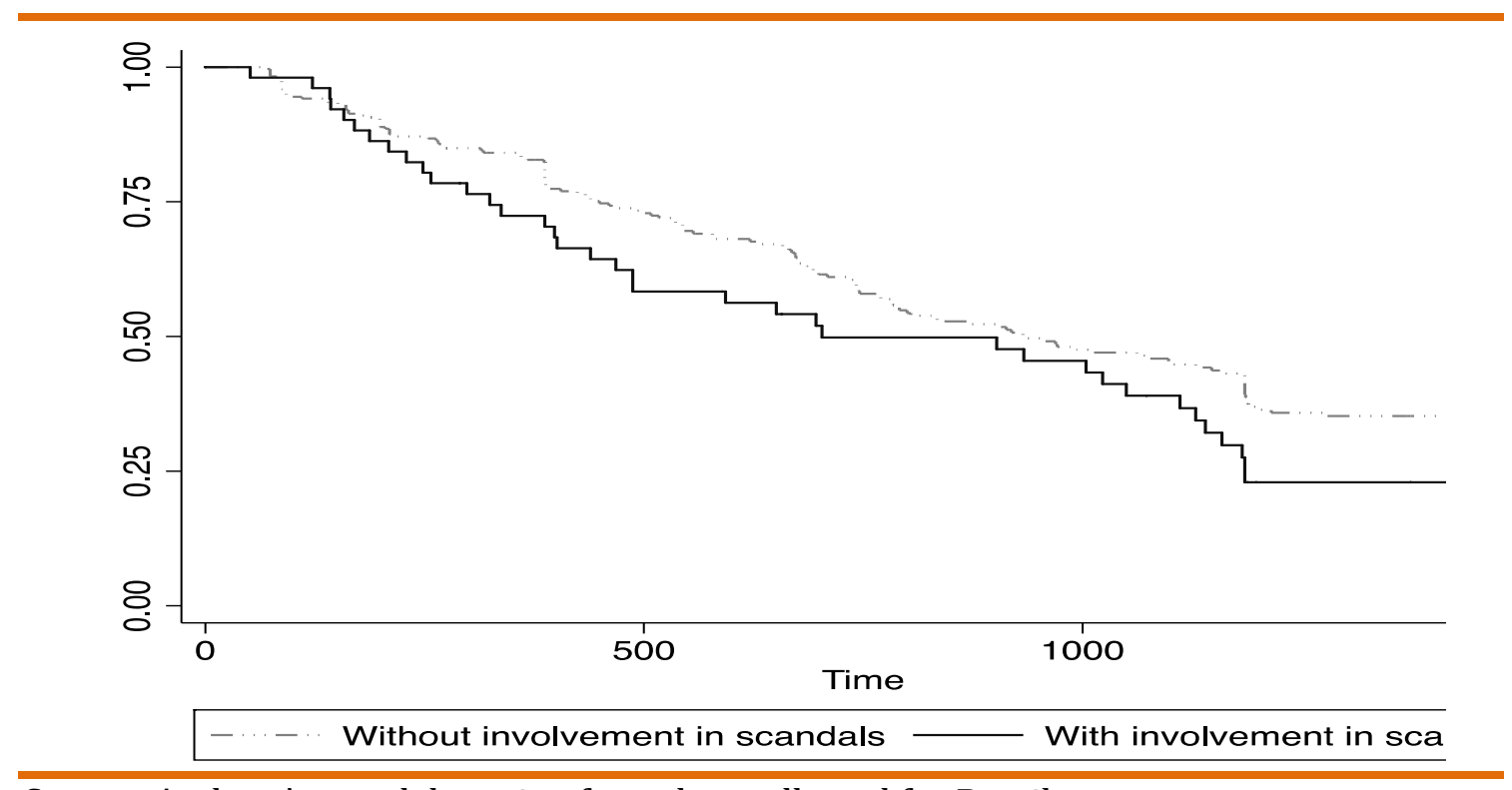

Source: Authors' own elaboration from data collected for Brazil.

At around the 1000-day mark in a presidential term, the curves get closer again, although they do not change places, and this can indicate a loss of statistical significance for the difference between them. The log-rank test presents statistically significant evidence on the distinction between curves, 
confirming that this effect is probably not isolated from other intervening factors, given its lower statistical significance (chi2 (1) $=3.10 ; p=0.078$ ).

From these initial descriptive statistics and the research hypotheses previously outlined, a survival analysis will be performed for the dependent variable that points to the event which ends a ministerial appointment before the end of the presidential term.

\section{Results - survival analysis}

Table 03 summarizes six different models of survival analysis. The observations did not present proportional risks for the application of the Cox model, which led to the use of a parametric model. After some statistical tests, the Weibull distribution was identified as the most suitable for the analysis of data observed, which means that there was variation of risks over time. As this model refers to the effect of co-variables on survival time, positive coefficients indicate that the higher the covariate value, the greater the probability of survival; negative coefficients, in turn, imply that the higher the value of the covariate, the lower the probability of survival, that is, keeping a ministerial post in the cabinet.

The first model indicates the negative effects of the IMP on ministerial tenure, with the other variables constant. The more politicized a minister is, the lower the probability of surviving, at a level of statistical significance of 1\%. It is also verified that ideological differences when considered alone do not have statistically significant effects on the dismissal of ministers. The variables of mediareported scandals and protests were not statistically significant either, nor were those that indicate the type of party affiliation.

The second model adds areas of government. Appointments to ministries in the areas of political articulation and State functions, when compared with central ministries, and maintaining the other variables constant, showed increased probability of ministerial survival, with statistical significance at the level of $5 \%$. These results were initially observed in the descriptive statistics. Moreover, ideological differences, political scandals and protests remained without statistical significance.

The addition of the factors of the ministers' political articulation the existence of ties with clients in the ministries, personal connections with the 
president and kinship with politicians - did not substantively alter the results. The fourth model, which adds socio-demographic variables, did not alter any of the observed results. The IMP remained statistically significant at the level of $1 \%$. The variables of media-reported scandals, protests and ideological differences still did not present statistical significance.

Table 03. Survival analysis for dismissal of a minister before the end of the term (coefficients of the Weibull distribution)

\begin{tabular}{|c|c|c|c|c|c|c|c|}
\hline Vari & ables & Model 01 & Model 02 & Model 03 & Model 04 & Model 05 & Model 06 \\
\hline Index of Mini & sterial & -0.170 & -0.162 & -0.183 & -01.184 & -0.133 & -0.137 \\
\hline Politicization & (IMP) & $(0.045)^{* * *}$ & $(0.047)^{* * *}$ & $(0.048)^{* * *}$ & $(0.048)^{* * *}$ & $(0.047)^{* * *}$ & $(0.046)^{* * *}$ \\
\hline & Same party & 0.022 & 0.069 & 0.145 & 0.120 & -0.131 & -0.164 \\
\hline Party & as president & (0.207) & $(0.222)$ & $(0.230)$ & $(0.235)$ & $(0.230)$ & $(0.224)$ \\
\hline affiliation & & -0.080 & -0.048 & -0.037 & -0.061 & -0.276 & -0.416 \\
\hline & Amlieu Dase & $(0.277)$ & $(0.292)$ & $(0.292)$ & $(0.297)$ & $(0.289)$ & $(0.283)$ \\
\hline Ideologicald & fforence & 0.015 & 0.009 & 0.024 & 0.038 & 0.041 & 0.205 \\
\hline Ideorogical a & Irerence & $(0.117)$ & (0.119) & $(0.117)$ & $(0.118)$ & $(0.114)$ & (0.127) \\
\hline Scondalc & & 0.037 & -0.003 & 0.021 & 0.000 & -0.050 & 0.383 \\
\hline scandals & & $(0.161)$ & $(0.166)$ & $(0.169)$ & $(0.172)$ & $(0.170)$ & $(0.231)^{*}$ \\
\hline Scandals* Ide & ological & & & & & & -0.529 \\
\hline difference & & & & & & & $(0.175)^{* * *}$ \\
\hline Protects & & -0.161 & -0.137 & -0.137 & -0.167 & -0.124 & -0.099 \\
\hline 1 1 & & $(0.192)$ & (0.198) & (0.199) & $(0.202)$ & $(0.196)$ & (0.189) \\
\hline & $\begin{array}{l}\text { Public } \\
\text { policy }\end{array}$ & & 0.133 & 0.139 & 0.163 & 0.165 & 0.170 \\
\hline & $\begin{array}{l}\text { implementa } \\
\text { tion }\end{array}$ & & (0.161) & (0.161) & (0.171) & $(0.164)$ & $(0.162)$ \\
\hline Government & $\begin{array}{l}\text { Area of } \\
\text { political }\end{array}$ & & 0.606 & 0.582 & 0.586 & 0.506 & 0.492 \\
\hline Area & $\begin{array}{l}\text { articulation } \\
\text { and State } \\
\text { functions }\end{array}$ & & $(0.260)^{* *}$ & $(0.259)^{* *}$ & $(0.269)^{* *}$ & $(0.255)^{* *}$ & $(0.247)^{* *}$ \\
\hline & $\begin{array}{l}\text { Presidency } \\
\text { and minor }\end{array}$ & & 0.250 & 0.284 & 0.340 & 0.181 & 0.201 \\
\hline & ministers & & $(0.190)$ & $(0.190)$ & $(0.207)$ & $(0.204)$ & $(0.200)$ \\
\hline Families of & liticians & & & 0.357 & 0.331 & 0.257 & 0.248 \\
\hline Famines or $\mathrm{p}$ & ilticlans & & & $(0.194)^{*}$ & $(0.197)^{*}$ & $(0.189)$ & $(0.185)$ \\
\hline Friends of th & president & & & -0.027 & 0.002 & 0.050 & -0.025 \\
\hline & & & & $(0.199)$ & $(0.209)$ & $(0.201)$ & $(0.195)$ \\
\hline Ministerial cl & ents & & & 0.113 & 0.143 & 0.148 & 0.196 \\
\hline 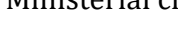 & Eilts & & & (0.183) & $(0.186)$ & $(0.180)$ & $(0.175)$ \\
\hline Women & & & & & -0.065 & -0.137 & -0.104 \\
\hline & & & & & $(0.243)$ & $(0.244)$ & $(0.237)$ \\
\hline
\end{tabular}




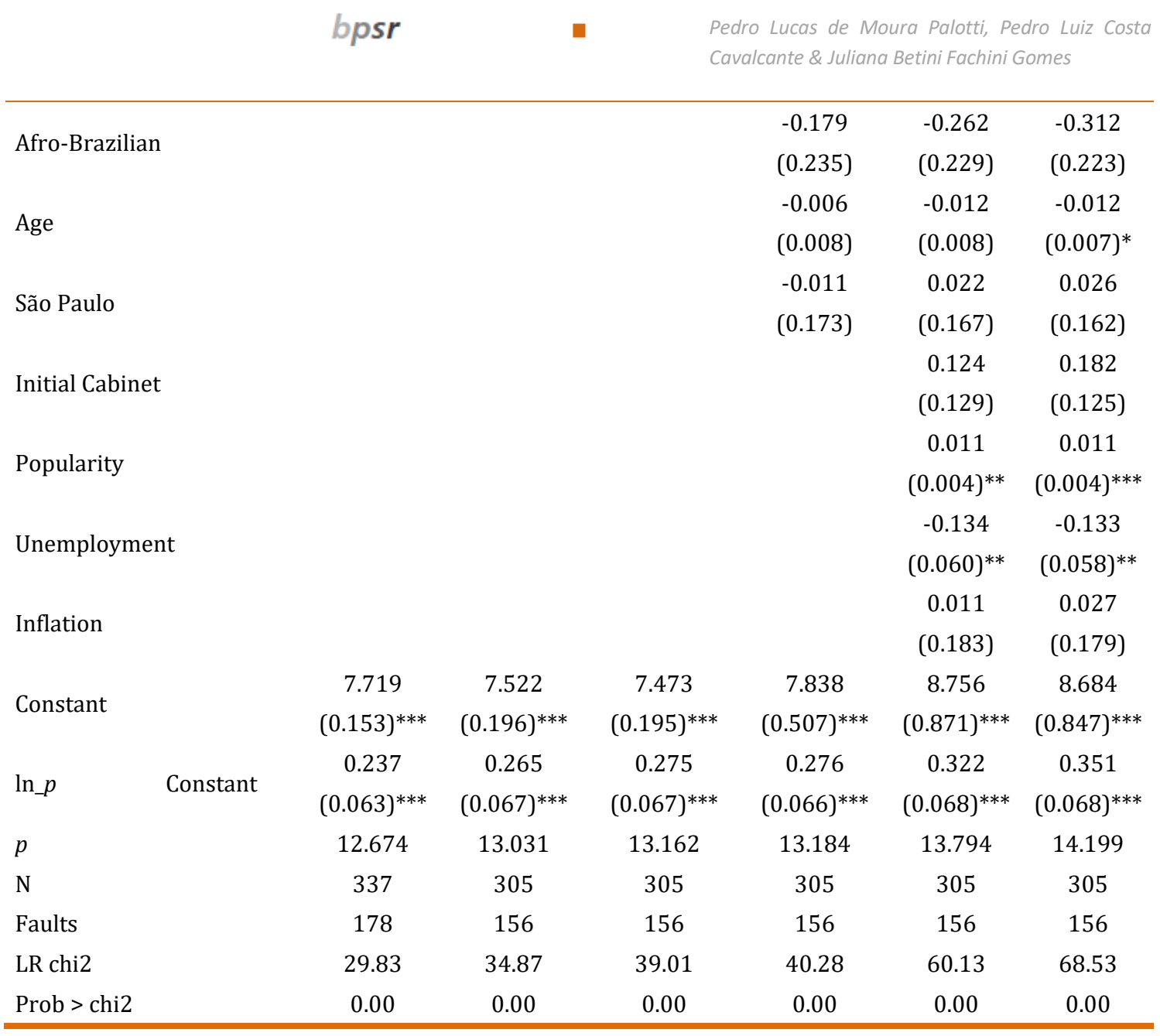

Source: Authors' own elaboration from data collected for Brazil.

Notes: ${ }^{*} p<0.1{ }^{* *} p<0.05$; ${ }^{* * *} p<0.01$. Standard errors between brackets.

The variable of 'political family' became statistically significant in two models. This indicates that belonging to traditional political families can contribute to increasing the probability of survival in a ministerial post. However, adding the variables of the last two models results in the loss of statistical significance for this variable. In any case, the statistical significance of 'political family' was already less robust, at $10 \%$.

The fifth model adds the additional controls of macroeconomic indicators, rates of inflation and unemployment, as well as presidential popularity. All of these variables were measured for the third month prior to the dismissal of the minister, to provide an idea of the lagged effects of these factors. The variables of the IMP and the political articulation and State functions areas remain statistically significant. Media-reported scandals, protests and ideological differences remain without statistical significance. 
Presidential popularity has a positive impact on the survival of ministers, being statistically significant at the level of $1 \%$. The unemployment rate is also statistically relevant, contributing negatively to the probability of ministerial survival. Thus, with each increase in presidential popularity, ministers are more likely to survive in office; conversely, there is an inverse correlation between the unemployment rate and the length of ministerial tenure.

The sixth and last model observed in Table 03 differs from the others by the insertion of an interactive term between ideological difference and media-reported scandals. This interaction presents a negative coefficient. In other words, the greater the ideological difference between the president and his or her main ministers, as measured by the ideological positioning of their respective parties, the lower the probability of maintaining their position. Statistical significance for this relationship occurred at the level of $1 \%$. The media-reported scandals variable, in turn, is positive when ideological distance is equal to zero, with statistical significance at the level of $10 \%$. Ministers with no party affiliation or minimal ideological distance from the president, as with their own party representatives, are highly likely to retain their posts even when faced with media-reported scandals. This relationship will be approached in greater detail below, by the graphical analysis of marginal effects. Ideological difference in the absence of scandals, was not statistically significant (by a very small margin ( $p=0.107)$ ). More ideologically distant ministers not facing scandal tend towards stability in office. The protests variable remained without statistical significance.

It is observed that, in none of the models, were gender and race variables statistically significant. The initial cabinet also does not present itself as a satisfactory explanatory factor to understand individual ministerial turnover. Age at nomination becomes statistically significant, pointing to a lower probability of staying in cabinet with an increase in the age, with statistical significance at the level of $10 \%$. In all models, party affiliation was not statistically significant. Withdrawal of party affiliation did not substantially alter the results obtained and previously reported. 
The presence of interaction effects between ideological distance and scandalreporting on the ministerial survival can be modeled using recent statistical techniques ${ }^{13}$.

When applied to survival analysis, the graphical representation corresponds to the effect of the 'treatment' or binary variable. The difference between the two functions - one with and the other without the presence of the binary variable - is calculated against the values of ideological distance, which are then represented graphically. Using this method, the variations of the effects of the binary variable, given the different ideological distance values, can be observed.

Figure 07 is a graphical representation of the statistically significant interaction observed in the sixth model, from the graphical model proposed by Royston and Sauerbrei (2009). Keeping the other variables constant, when there are media scandals, the greater the ideological distance between minister and the president, the lower the chance of survival for the minister in his or her current position.

Thus, at the beginning of the interaction, when the ideological distance is zero or close to it, the existence of media-reported scandals has no effect on ministerial tenure. The straight line and the confidence interval pass through zero. The effect, however, changes with the widening of the ideological difference between the president and the minister. After the ideological difference exceeds the value 01 , as this distance increases, coefficients become statistically significant and negative. In this sense, in the presence of media scandals, the greater the ideological distance in relation to the chief of the Executive, the less likely the survival of ministerial appointments.

\footnotetext{
${ }^{13}$ Royston and Sauerbrei (2009) present the solution of multivariate interaction of fractional polynomials for cases involving an interaction between a continuous variable and a categorical one, as in medical experiments. This method is a more suitable alternative to the traditional approach of categorizing the continuous factors for the application of standardized tests of interaction.
} 
Figure 07. Effect of ideological differences on the survival of ministers subjected to media scandals, following model 06 (Weibull)

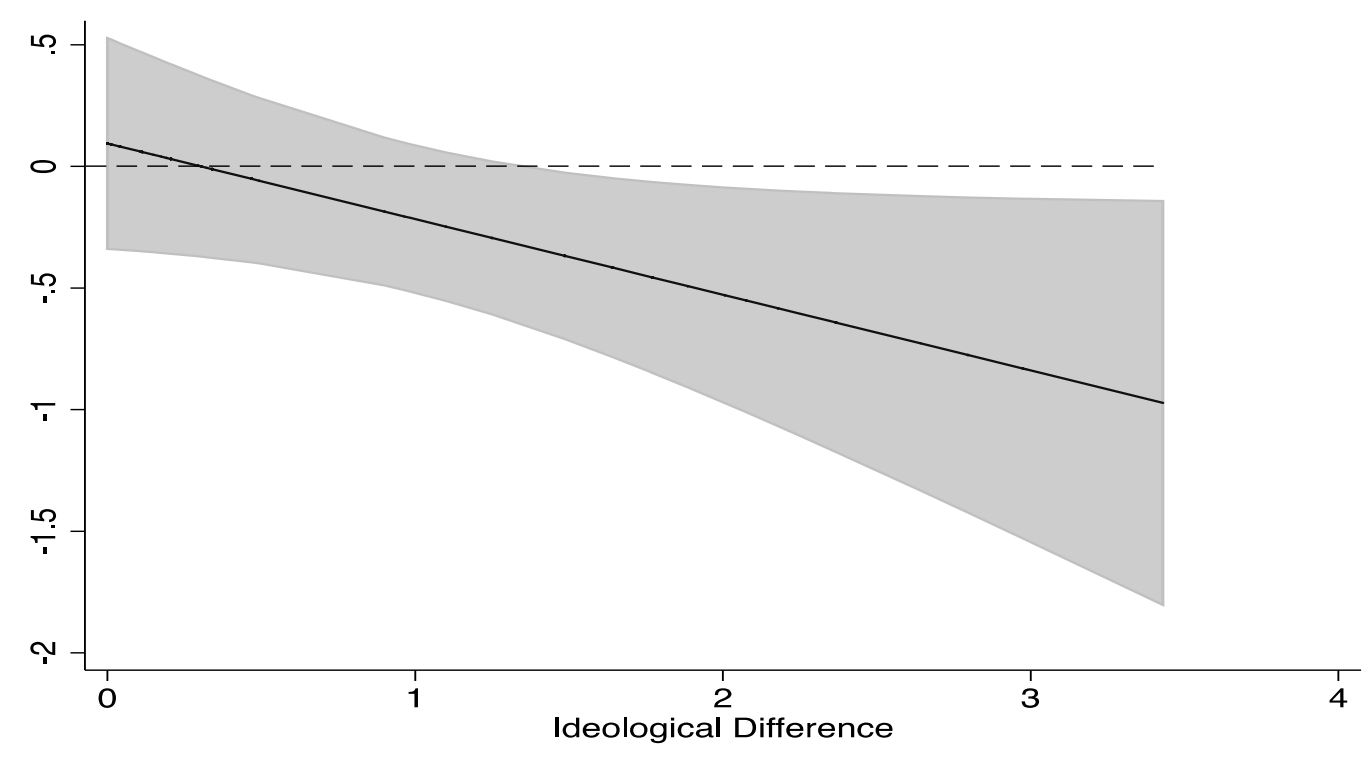

Source: Authors' own elaboration from data collected for Brazil.

Notes: Vertical axis values correspond to the conditioned coefficients of the Weibull regression with 95\% confidence interval.

\section{Final remarks}

This paper tested the usual explanations for the exit of ministers before the end of a four-year presidential term, using the case of the Brazilian presidential system from 1995 to 2014 . For this purpose, we considered the variables of profile, professional career, political and socio-demographic features, composition of specific ministries and the occurrence of external shocks, such as scandals and protests covered by the media, as well as macroeconomic and presidential popularity indicators.

The models' results confirm the $\mathrm{H} 1$ hypothesis. Consistently, in all models, with robust statistical significance, the greater the politicization, the shorter the time in cabinet. This finding is consonant with that identified by Cavalcante and Palotti (2015), who use two independent indicators to measure the technical and political aspects of the ministers, including two other administrations - Collor (1990 to 1992) and Franco (1992 to 1995). In this paper, the degree of politicization was measured using the Index of Ministerial Politicization (IMP). 
Thus, even after a new measurement, the H1 hypothesis remains valid. Individual political ambition and political-partisan projects interfere with the ministerial tenure. Under the Brazilian law, ministers wishing to withdraw from office must do so at least six months before the next election. In this sense, greater involvement in the party and electoral arena are subject to the constraints of the powers delegated by political parties, even when the party in question is not the president' party (MARTÍNEZ-GALLARDO and SCHLEITER, 2014; WIESEHOMEIER and BENOIT, 2009).

The H2 hypothesis could not initially be confirmed by the regression model. Ideological distance points in the opposite direction to the proposed causality: ministers more ideologically distant from the president tend to remain in cabinet longer. However, this coefficient is not statistically significant, although in the latter model, in the presence of interaction with media-reported scandals, it approaches the threshold of conventionally acceptable minimum statistical significance.

It is possible to infer that greater scrutiny prior to an appointment by the president is a condition of ministerial selection. More popular chiefs of the Executive have greater autonomy to vet and propose names, and can take lead roles as coalition builders. Likewise, unpopularity and recurring conflicts with coalition partners may force the president to accept indications that will later prove unsatisfactory. Problems derived from poor selection may therefore depend on a combination of factors that interfere with the observation of the expected relationship between ideological distance and ministerial turnover. Data collected on future administrations should help unravel this relationship.

The area of the presidency being responsible for political articulation and State functions tends to shelter more stable ministers compared to the more politically attractive core areas of government. Although not initially considered, it is reasonable to suppose that the explanation is close to the logic proposed for the H2 hypothesis. Poor selection problems are avoided for this area of government by not appointing allied ministers; this results in more scrutiny prior to appointment and greater ministerial stability thereafter. Coalition dynamics remain relevant in influencing presidential responses to media-reported scandals involving ministers.

The H3 hypothesis, when observing in isolation the occurrence of mediareported scandals involving ministers, is not supported by empirical evidence. 
However, it is supported by observing the derived hypothesis, H3.1. Presidents care about public opinion, and are permanently exposed to it. A president's accountability in response to media reports, especially of personal and corruption scandals, is conditioned by ideological distance from ministers. The strengthening of control bodies, in combination with a free press, as in Brazil, result in several checks that limit the action of strong presidents (MELO and PEREIRA, 2013). Scandals act as alarm mechanisms for presidents, advising them of the existence of unwanted deviations coming from ideologically distant auxiliaries.

Therefore, ministers involved in scandals who are closer to the ideological mainstream of a coalition are less likely to be replaced than those who are more distant. Although at the macro level presidents react to scandals, it is observed that these responses are not equal, and depend on the affinity of the staff involved. These findings corroborate the evidence presented by Araújo, Costa, and Fittipaldi (2016) for the first two years of the Rousseff government, tested here for the 20-year period beginning with the first Cardoso administration. They also confirm that presidents apply differential treatment to their most ideologically distant coalition partners, which in other studies have been identified as being less likely to participate in decision-making processes (GAYLORD and RENNÓ, 2015; SILVA, 2014).

The results obtained for the variables unemployment rate and presidential popularity are consistent with the presidential responsiveness argument, in this case due to unsatisfactory performance rather than episodic events such as media scandals. Chiefs of the Executive in presidential regimes are directly exposed to evaluation via public opinion and appear to use the ministerial reshuffles to produce changes that reflect governmental responsiveness.

In the last model, it is observed that age on taking office was statistically significant; the older a minister, the shorter their time in office. This result goes against the assumption that younger ministers are more likely to leave the cabinet in order to preserve their political careers, while more experienced ministers, upon leaving the cabinet, are likely to end their working lives (BERLINSKI et al., 2009). Future research should test the extent of this and investigate which factors may influence ministerial tenure according to age. It is also worth noting the lack of statistical significance relating to gender, race and the initial composition of the 
cabinet, which indicates that these factors do not interfere with decisions to retain, change or dismiss state ministers in Brazil.

Thus, it is argued that all three sets of explanations initially presented are relevant for understanding ministerial turnover. Ministers, by entering in the world of politics, create links and situations that constrain their tenure, and are mainly driven by political ambition. Government coalitions, in turn, involve multiple principals and asymmetrical treatment by presidents of their auxiliaries. Finally, media-reported scandals constitute constraints and alarms that mobilize presidential attention. Presidents tends, when faced with media reporting of scandals, to fire ministers who are ideologically more distant from them. This finding represents an original explanation for ministerial turnover. It comes primarily from a presidential decision influenced by the factors of multiparty coalition government and external shocks.

In sum, the paper's findings contribute to the advancement of the field of study insofar as it explores the main theories of the literature on ministerial turnover applied to a new and dynamic democracy. Brazil is most certainly a suitable laboratory for this type of analysis, due to its coalition presidentialism, its multiparty system and its politicians' constant involvement in scandals, and this article sought to analyze ministerial stability with a comprehensive and unprecedented review of the local literature on the subject. This study gives an extensive and multi-causal answer to minister turnover in multiparty systems as Brazil.

The emphasis of political science studies has been on understanding the joint composition of cabinets, rather than the choice or replacement of individual ministers. The explanatory factors for a cabinet's initial composition, however, do not explain its later conformation. Observing the durability of cabinets allows progress on knowledge about the macro functioning of governments, while focusing on ministerial tenure helps understand how they function at the micro level. These approaches generate implications for the accountability and effectiveness of governmental actions.

Revised by Fraser Robinson

Submitted on April 03, 2018

Accepted on May 06, 2019 


\section{References}

ABRANCHES, Sérgio Henrique Hudson (1988), Presidencialismo de coalizão: o dilema institucional brasileiro. Dados. Vol. 31, № 01, pp. 05-38.

AMORIM NETO, Octavio (2006), The presidential calculus: executive policy making and cabinet formation in the Americas. Comparative Political Studies. Vol. 39, № 04, pp. 415-440.

ARAUJO, Cletiane Medeiros; COSTA, Saulo Felipe, and FITTIPALDI, Ítalo (2016), Boa noite, e boa sorte: determinantes da demissão de ministros envolvidos em escândalos de corrupção no primeiro governo Dilma Rousseff. Opinião Pública. Vol. 22, № 01, pp. 93-117.

BERLINSKI, Samuel; DEWAN, Torun; DOWDING, Keith, and SUBRAHMANYAM, Gita (2009), Choosing, moving and resigning at Westminster, UK. In: The selection of ministers in Europe: hiring and firing. Edited by DOWDING, Keith and DUMONT, Patrick. London: Routledge. pp. 58-78.

BORGES, André, and COELHO, Denilson B. (2015), O preenchimento de cargos da burocracia pública federal no presidencialismo de coalizão brasileiro: análise comparada de dois ministérios - Ciência e Tecnologia e Integração Nacional. In: Cargos de Confiança no Presidencialismo de Coalizão Brasileiro. Edited by LOPEZ, Felix Garcia. Brasília: Editora IPEA. pp. 71-105.

CAMERLO, Marcelo and PÉREZ-LIÑÁN, Aníbal (2015a), Minister turnover, critical events, and the electoral calendar in presidential democracies. The Journal of Politics. Vol. 77, № 03, pp. 608-619.

CAMERLO, Marcelo and PÉREZ-LIÑÁN, Aníbal (2015b), The politics of minister retention in presidential systems: technocrats, partisans, and government approval. Comparative Politics. Vol. 47, № 03, pp. 315-333.

CAMERLO, Marcelo and MARTÍNEZ- GALLARDO, Cecília ( Eds) (2018), Government formation and minister turnover in presidential cabinets: comparative analysis in the Americas. London and New York: 242 pp..

CAVALCANTE, Pedro and PALOTTI, Pedro (2015), What does it take to remain in office? Minister's profile and duration in a newly established democracy. Conference paper presented at 73rd Anual MPSA Conference, Chicago.

CODATO, Adriano, and FRANZ, Paulo (2018), Ministros-técnicos e ministrospolíticos nos governos do PSDB e do PT. Revista de Administração Pública. Vol. 52, № 05, pp. 776-796.

D'ARAUJO, Maria Celina Soares and RIBEIRO, Guilherme Leite (2018), Trajetória socioeducacional dos ministros brasileiros na Nova República (1985-2014). Revista de Sociologia e Política. Vol. 26, № 65, pp. 39-61. 
DIERMEIER, Daniel and MERLO, Antonio Merlo (2000), Government turnover in parliamentary democracies. Journal of Economic Theory. Vol. 94, № 01, pp. 4679.

DIXIT, Avinash (1997), Power of incentives in private versus public organizations. American Economic Review. Vol. 87, № 02, pp. 378-382.

DOWDING, Keith and DUMONT, Patrick (2009), Structural and strategic factors affecting the hiring and firing of ministers. In: The selection of ministers in Europe: hiring and firing. Edited by DOWDING, Keith and DUMONT, Patrick. London: Routledge. pp. 01-20.

DRUCKMAN, James N. and WARWICK, Paul V. (2005), The missing piece: measuring portfolio salience in Western European parliamentary democracies. European Journal of Political Research. Vol. 44, № 01, pp. 17-42.

ESCOBAR-LEMMON, Maria C. and TAYLOR-ROBINSON, Michelle M. (2010), Coming or going: how background affects duration in 05 presidential systems. Paper presented at the American Political Science Association Meeting. Washington.

FIGUEIREDO, Argelina Cheibub and LIMONGI, Fernando (eds) (1999), Poder de agenda, disciplina e apoio partidário na Câmara dos Deputados. In: Executivo e Legislativo na Nova Ordem Constitucional.Rio de Janeiro: FGV. pp. 101-124.

FISCHER, Germany Jörn, and KAISER, André (2008), Hiring and firing ministers under informal constraints: Germany. In: The selection of ministers in Europe: hiring and firing. Edited by DOWDING, Keith and DUMONT, Patrick. London: Routledge. pp. 39-58.

GAILMARD, Sean (2009), Multiple principals and oversight of bureaucratic policymaking. Journal of Theoretical Politics. Vol. 21, № 02, pp. 161-186.

GAYLORD, Sylvia, and RENNÓ, Lucio (2015), Opening the black box: cabinet authorship of legislative proposals in a multiparty presidential system. Presidential Studies Quarterly. Vol. 45, № 02, pp. 247-269.

GONZÁLEZ-BUSTAMANTE, Bastián and OLIVARES, Alejandro (2016), Cambios de gabinete y supervivencia de los ministros en Chile durante los gobiernos de la Concertación (1990-2010). Colombia Internacional. Vol. 87, pp. 81-108.

GROSSMAN, Emiliano (2009), The President's choice? Government and cabinet turnover under the Fifth Republic. West European Politics. Vol. 32, № 02, pp. 268-286.

GROSSMAN, Emiliano and FRANÇOIS, Abel (2013), Who are the ministers of the Fifth Republic? French Politics. Vol. 11, № 03, pp. 272-283. 
HAIR JR., Joseph F.; BLACK, William C.; BABIN, Barry J., and ANDERSON, Rolph E. (2014), Multivariate data analysis. London: Pearson New International Edition. 740 pp..

HUBER, John D. (1998), How does cabinet instability affect political performance? Portfolio volatility and health care cost containment in parliamentary democracies. American Political Science Review. Vol. 92, № 03, pp. 577-591.

HUBER, John D. and MARTINEZ-GALLARDO, Cecilia (2004), Cabinet instability and the accumulation of experience: The French Fourth and Fifth Republics in comparative perspective. British Journal of Political Science. Vol. 34, № 01, pp. 27-48.

HUBER, John D. and MARTINEZ-GALLARDO, Cecilia (2008), Replacing cabinet ministers: patterns of ministerial stability in parliamentary democracies. American Political Science Review. Vol. 102, № 02, pp. 169-180.

KRISTINSSON, Gunnar Helgi (2009), More safe than sound? Cabinet ministers in Iceland. In: The selection of ministers in Europe: hiring and firing. Edited by DOWDING, Keith and DUMONT, Patrick. London: Routledge. pp. 194-203.

MARTÍNEZ-GALLARDO, Cecilia (2010), Inside the cabinet: the influence of ministers in the policymaking process. In: How democracy works: political institutions, actors, and arenas in Latin American policymaking. Edited by SCARTASCINI, Carlos; TOMMASI, Mariano, and STEIN, Ernesto. Cambridge: Inter American Development Bank. pp. 119-146.

MARTÍNEZ-GALLARDO, Cecilia (2011), Designing cabinets: presidential politics and cabinet instability in Latin America. Paper n⿳0 375, published by Kellogg Institute For International Studies.

MARTÍNEZ-GALLARDO, Cecilia and SCHLEITER, Petra (2014), Choosing whom to trust: agency risks and cabinet partisanship in presidential democracies. Comparative Political Studies. Vol. 48, № 02, pp. 231-264.

MAUERBERG JR., Arnaldo (2016), Cabinet composition and assessment of a multiparty presidential system. Doctoral Thesis. Escola de Administração de Empresas de São Paulo. Fundação Getúlio Vargas.

MELO, Marcos André and PEREIRA, Carlos (2013), Making Brazil work: checking the president in a multiparty system. London: Palgrave Macmillan. 212 pp..

PALOTTI, Pedro Lucas de Moura (2017), Estratégias de seleção e substituição de ministros de Estado no presidencialismo de coalizão brasileiro: perfil, alocação e rotatividade. Doctoral Thesis. Instituto de Ciência Política. Universidade de Brasília. 
PALOTTI, Pedro Lucas de Moura and CAVALCANTE, Pedro Luiz Costa Cavalcante (2018), Does one size fit all? An analysis of portfolio allocation in the Brazilian multiparty presidential system. Opinião Pública. Vol. 24, № 02, pp. 427-455.

PEREIRA, Carlos; BERTHOLINI, Frederico, and RAILE, Eric D. (2016), All the President's men and women: coalition management strategies and governing costs in a multiparty presidency. Presidential Studies Quarterly. Vol. 46, № 03, pp. 550-568.

PINTO, Antonio Costa and ALMEIDA, Pedro Tavares de (2009), Portugal: the primacy of 'independents'. In: The selection of ministers in Europe: hiring and firing. Edited by DOWDING, Keith and DUMONT, Patrick. London: Routledge. pp. 147-158.

RAILE, Eric D.; PEREIRA, Carlos, and POWER, Timothy J. (2011), The executive toolbox: building legislative support in a multiparty presidential regime. Political Research Quarterly. Vol. 64, № 02, pp. 323-334.

ROYSTON, Patrick, and SAUERBREI, Willi (2009), Two techniques for investigating interactions between treatment and continuous covariates in clinical trials. Stata Journal. Vol. 09, № 02, pp. 230-251.

SILVA, Mariana Batista da (2014), 0 mistério dos ministérios: a governança da coalizão no presidencialismo brasileiro. Doctoral Thesis. Centro de Filosofia e Ciências Humanas. Programa de Pós-Graduação em Ciência Política. Universidade Federal de Pernambuco (UFPE).

STEIN, Ernesto; TOMMASI, Mariano; ECHEBARRÍA, Koldo; LORA, Eduardo, and PAYNE, Mark (2006), The politics of policies: economic and social progress in Latin America. 2006 Report. Cambridge: Inter-American Development Bank and David Rockefeller Center for Latin American Studies. 330 pp..

STRØM, Kaare (2000), Delegation and accountability in parliamentary democracies. European Journal of Political Research. Vol. 37, № 03, pp. 261-290.

VERZICHELLI, Luca (2009), Italy: the difficult road towards a more effective process of ministerial selection. In: The selection of ministers in Europe: hiring and firing. Edited by DOWDING, Keith and DUMONT, Patrick. London: Routledge. pp. 97118.

WIESEHOMEIER, Nina, and BENOIT, Kenneth (2009), Presidents, parties, and policy competition. The Journal of Politics. Vol. 71, № 04, pp. 1435-1447. 